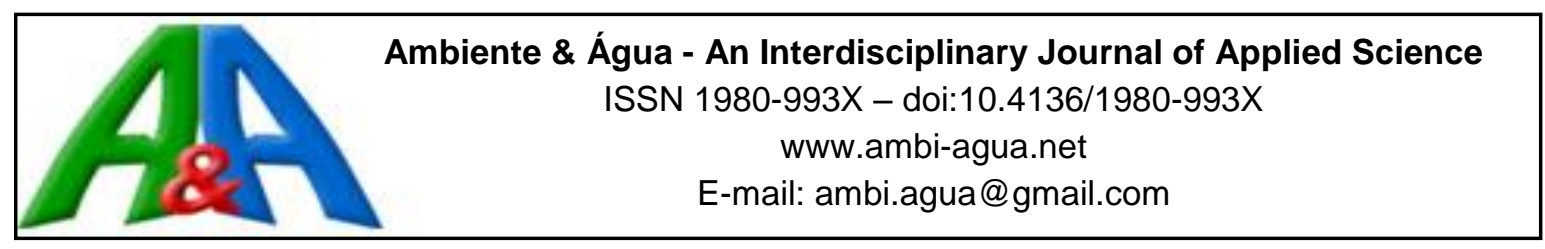

\title{
The degradation of methylene blue dye by the strains of Pleurotus sp. with potential applications in bioremediation processes
}

\author{
ARTICLES doi:10.4136/ambi-agua.2247 \\ Received: 22 Feb. 2018; Accepted: 17 May 2018
}

\begin{abstract}
Adriele Santos Van Der Maas; Nazareth Jordelina Ribeiro da Silva; Alexandre Sylvio Vieira da Costa; Aruana Rocha Barros; Cleide Aparecida Bomfeti*
\end{abstract}

\begin{abstract}
Universidade Federal dos Vales do Jequitinhonha e Mucuri (UFVJM), Teófilo Otoni, MG, Brasil Instituto de Ciências, Engenharia e Tecnologia (ICET). E-mail: adrielemaas@gmail.com, nazarethr.silva@hotmail.com, alexandre.costa@ufvjm.edu.br, aruana.barros@ufvjm.edu.br, clebomfeti@hotmail.com

*Corresponding author
\end{abstract}

\begin{abstract}
Fungi have a large capacity to produce enzymes that are capable of degrading compounds. In this regard, soluble dyes are often used as a means of evaluating and selecting strains with potential for biodegradation. This study verified the capacity of the strains of Pleurotus sp. in degrading methylene blue dye, in order to identify the strains with potential for the bioremediation. For this reason, a total of seven strains of Pleurotus sp. were grown in a potato liquid medium with the methylene blue dye at the concentrations of $0.02 \mathrm{~g} \mathrm{~L}^{-1}$ and $0.04 \mathrm{~g} \mathrm{~L}^{-1}$. The results of the absorbances showed that all the isolates were visibly able to reduce the media staining following seven days of growth. However, a reduction of approximately $80 \%$ in the staining was observed for the strains named ERY, HI, and SB compared to the control. Thus, it was observed that these strains could be used in the color removal bioprocesses and in the biodegradation of pollutant compounds.
\end{abstract}

Keywords: absorbance, discoloration, fungi.

\section{Degradação do corante azul de metileno por linhagens de Pleurotus sp. com potencial aplicação em processos de biorremediação}

\section{RESUMO}

Os fungos têm uma grande capacidade para produzir enzimas que são capazes de degradar compostos. De acordo com esse fato, os corantes solúveis são frequentemente utilizados como maneira de avaliação e seleção de linhagens com potencial de biodegradação. O presente estudo verificou a capacidade de linhagens de Pleurotus sp. na degradação do corante azul de metileno, a fim de identificar linhagens com potencial para processos de biorremediação. Desse modo, um total de sete linhagens de Pleurotus sp. foram cultivadas em meio líquido de batata com o corante azul de metileno nas concentrações de $0,02 \mathrm{~g} \mathrm{~L}^{-1}$ e $0,04 \mathrm{~g} \mathrm{~L}^{-1}$. Os resultados das absorvâncias mostraram que todos os isolados foram visivelmente capazes de reduzir a coloração do meio, após sete dias de crescimento fúngico. Observou-se ainda, uma redução de aproximadamente $80 \%$ na coloração para as linhagens denominadas ERY, HI e SB em comparação com o controle. Assim, foi possível constatar que essas linhagens podem ser 
utilizadas em bioprocessos de remoção de cor e na biodegradação de compostos poluentes.

Palavras-chave: absorbância, descoloração, fungo.

\section{INTRODUCTION}

In the different cities of Brazil, environmental pollution is directly related to the disorderly growth of the urban population and the lack of basic sanitation. The improper dumping of toxic effluents into the rivers has left them with large deposits of toxic metals and other substances that are difficult to degrade. Due to this situation, there is a need to restore these ecosystems through planned interventions, rebuild their structures, and create conditions for restoring the natural ecological processes of each environment (Soares et al., 2011).

One of the alternatives to solving this problem is the use of bioremediation processes, which are treatments performed through the use of living organisms, efficient and adequate in the process of minimization or even in the complete elimination of pollutants in the impacted environment. Several organisms can be used as bioremediation agents in the environment, depending mainly on the presence of microorganisms capable of metabolizing the original molecules and the products of their degradation (Cajthaml, 2015).

The fungi are a group of promising microorganisms for studies and also for application as bioremediation agents since they present a series of economic, ecological, and potential characteristics to degrade recalcitrant compounds through their enzymatic systems (Atagana et al., 2006). Compared to other microorganisms, the use of the fungi in bioremediation processes is highly viable because they are able to rapidly adapt their metabolism to different sources of carbon to produce a large amount of intracellular and extracellular enzymes, responsible for the degradation, mineralization, and accumulation of the toxic materials (Kamida et al., 2005).

In addition to these factors, the fungi have a mode of growth that is chemostatically induced toward the source of organic carbon through the elongation and branching of hyphae, which allow the colonization of large areas. Thus, the superficial contacts with the contaminants are optimized, thereby increasing their bioavailability and consequently, their biodegradation (Przystaś et al., 2018).

Considering the characteristics presented by these organisms, studies in the area of biotechnology indicate that strains of Pleurotus sp. have a high potential as an agent in the recovery of environments contaminated by a variety of recalcitrant compounds (Zhuo et al., 2017). The fungi produce a high amount of mycelial mass and are considered good biosorbents due to the chemical composition of their cell walls and the mechanisms of their resistance to the conditions of environmental stress (Křesinová et al., 2018). The chemical composition of the cell walls of the fungi is responsible for attracting and retaining metals in the fungal biomass through the electrostatic interactions, a process known as biosorption (Gupta and Rastogi, 2009).

Due to the high degradative potential and the mechanisms of resistance under adverse environmental conditions, the use of the filamentous fungi and their metabolites has grown in recent years (Santana et al., 2016). In this regard, the use of the dyes, mainly methylene blue, as a selection method for identification of the lignolytic activity and the degradation capacity offers several benefits, including the development of simple, rapid, and quantitative spectrometric methods. Besides, dyes do not hinder the growth of organisms and their polymeric nature ensures that their degradation occurs extracellularly, at least in the initial stages (Pozdnyakova et al., 2018).

Therefore, this work verified the capacity of isolates of Pleurotus sp. in degrading methylene blue dye in order to identify some of the strains with potential for bioremediation processes. 


\section{MATERIALS AND METHODS}

\subsection{Isolation and maintenance of Pleurotus sp. strains}

For the realization of the experiments, a total of seven strains of fungi belonging to the genus Pleurotus were analyzed. A total of four strains were obtained from the in natura species, commercialized in the supermarkets of Belo Horizonte-MG and were named P1, P2, P3, and $\mathrm{P} 4$. For the isolation of the fungal mycelia from these mushrooms, acquired in supermarkets, fragments were extracted from the inner parts of the fungi and were isolated in Petri dishes, containing the potato dextrose agar (PDA) medium, previously sterilized in an autoclave at $121^{\circ} \mathrm{C}$ for $20 \mathrm{~min}$, followed by the addition of $50 \mu \mathrm{g} \mathrm{mL}^{-1}$ of ampicillin.

The other three strains, obtained from the Microorganisms Genetics Laboratory at the State University of Londrina, Londrina, PR, Brazil were identified as Pleurotus eryngii (ERY) and Pleurotus ostreatus (HI and SB).

The plates containing the strains of Pleurotus sp. were kept at $28^{\circ} \mathrm{C}$ until the medium surface was completely colonized by the fungal mycelia. Subsequently, all the strains were kept in a refrigerator at $4{ }^{\circ} \mathrm{C}$ and were periodically tested for maintenance.

\subsection{Growth of the fungi in the liquid medium}

Potato dextrose (PD) liquid medium was used for the growth of the fungal strains. After preparation, an aliquot of $3 \mathrm{~mL}$ of the liquid culture medium was transferred into test tubes and autoclaved at $121^{\circ} \mathrm{C}$ for $20 \mathrm{~min}$.

For each of the isolates of Pleurotus sp., a disk of $1 \mathrm{~cm}$ in diameter was removed from the mycelia growing in the solid medium and inoculated into test tubes, each containing $3 \mathrm{~mL}$ of the PD liquid medium. Subsequently, the test tubes containing the samples were incubated in a static incubator at $28^{\circ} \mathrm{C}$ for seven days.

\subsection{Preparation of the culture medium containing the methylene blue dye}

Using the PD culture medium, the experiments were performed by giving two treatments with the methylene blue dye at concentrations of $0.02 \mathrm{~g} \mathrm{~L}^{-1}$ and $0.04 \mathrm{~g} \mathrm{~L}^{-1}$, chosen according to Babá et al. (2009). Also, the PD control medium was prepared without the addition of the dye.

The solutions were prepared in $250 \mathrm{~mL}$ Erlenmeyer flasks, followed by the distribution of $100 \mathrm{~mL}$ of the PD liquid medium and the addition of the methylene blue dye at the different concentrations of $0.02 \mathrm{~g} \mathrm{~L}^{-1}$ and $0.04 \mathrm{~g} \mathrm{~L}^{-1}$. All the solutions were autoclaved at $121^{\circ} \mathrm{C}$ for $20 \mathrm{~min}$. After sterilization, each Erlenmeyer flask received $3 \mathrm{~mL}$ of the liquid culture medium, previously inoculated with the seven strains of Pleurotus sp. prepared in the test tubes as described above. All the treatments were performed in triplicate.

After this procedure, the flasks were incubated in an orbital incubator at $110 \mathrm{rpm}$ for seven days at $28^{\circ} \mathrm{C}$.

\subsection{Evaluation of mycelial growth}

The growth of fungal biomass was evaluated by the filtration of the treatments, using a funnel and Whatman N1 filter papers, weighed initially. After the procedure, the filter papers with the mycelial mass from each of the isolates were kept in a static incubator at $60^{\circ} \mathrm{C}$ until a constant weight was reached. Subsequently, the fungal mycelia were measured in an analytical balance and their masses were expressed in grams.

\subsection{Evaluation of the degradation of the methylene blue dye}

The supernatants from each of the seven isolates were evaluated by reading their absorbances on a spectrophotometer at a wavelength of $520 \mathrm{~nm}$. The absorbances of each of the final solutions inoculated with the fungal strains were compared to their respective initial solutions without the fungal inoculation, resulting in the percentage of degradation of the dye for each of the fungal isolates. 


\subsection{Statistical analysis}

All the statistical analyses were performed using the SPSS software version 2.1. The statistical methods used were ANOVA, followed by Tukey's test at the 5\% level of significance.

\section{RESULTS AND DISCUSSION}

It was observed that all of the isolates of Pleurotus sp. were able to grow at the different concentrations of the methylene blue dye (Figure 1).

The strains of Pleurotus sp. have the capacity to produce a significant amount of mycelial mass because of their efficiency, and being one of the most cultivated fungi, they have extensive applicability in biological processes. The fungi are able to grow in different media due to their ability to secrete enzymes to absorb the nutrients necessary for their development (Przystaś et al., 2018).

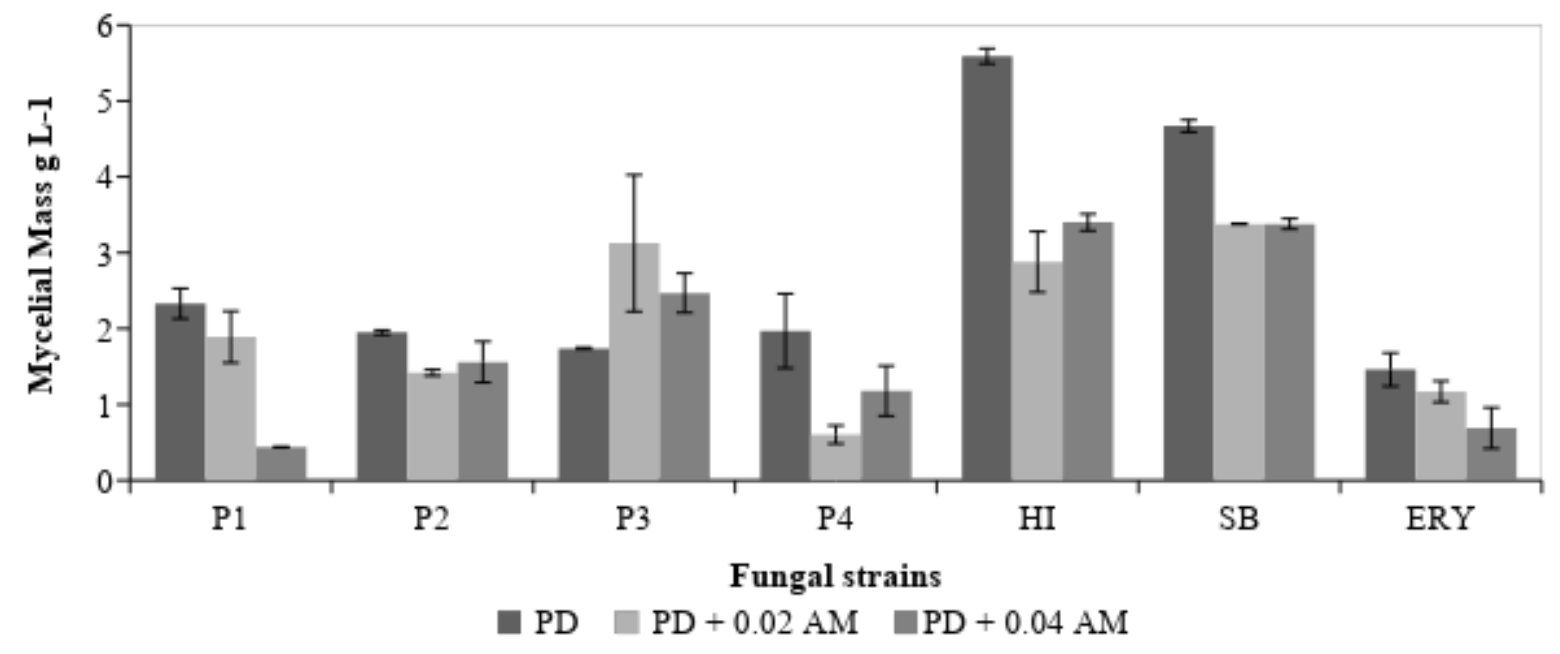

Figure 1. Mycelial mass production by the seven Pleurotus strains (P1, P2, P3, P4, HI, SB, ERY) after seven days of incubation at $28^{\circ} \mathrm{C}$ under agitation in the medium without the addition of methylene blue dye (PD); in the medium with the addition of $0.02 \mathrm{~g} \mathrm{~L}^{-1}$ of methylene blue (PD + $0.02 \mathrm{~g} \mathrm{~L}^{-1} \mathrm{AM}$ ); and in the medium with the addition of $0.04 \mathrm{gL}^{-1}$ of methylene blue (PD + $\left.0.04 \mathrm{~g} \mathrm{~L}^{-1} \mathrm{AM}\right)$.

The analysis of the production of fungal mycelial mass (Figure 1) showed that, except for isolate P3, almost all the isolates in the solution with the PD medium were able to produce a higher mycelial mass compared to the other solutions. Such a good development of the isolates in the PD medium can be attributed to the fact that the medium was composed of only glucose and potato, thereby generating a high capacity of development for the strains and becoming ideal for their growth. However, the addition of the dye resulted in a lower development of the fungi due to their necessity of expending energy for the degradation of this compound (Confortin et al., 2008).

In the solution with the PD medium, only strain P3 presented the lowest mycelial mass average, compared to the other solutions. However, as shown by Tukey's test at the 5\% level of probability in Table 1, this value did not differ significantly from the results of the P1, P2, P4, and ERY strains for this treatment. 
Table 1. Production of Mycelial Mass ( $\mathrm{g} \mathrm{L}^{-1}$ ) presented by Pleurotus strains (P1, P2, P3, P4, HI, SB, $\mathrm{ERY}$ ) for the treatments in the medium without addition of the methylene blue (PD); in the medium with the addition of $0.02 \mathrm{~g} \mathrm{~L}^{-1}$ of methylene blue (PD + AM $\left.0.02 \mathrm{~g} \mathrm{~L}^{-1}\right)$; and in the medium with the addition of $0.04 \mathrm{gL}^{-1}$ of the methylene blue dye (PD + AM $\left.0.04 \mathrm{~g} \mathrm{~L}^{-1}\right)$.

\begin{tabular}{lccccccc}
\hline \multirow{2}{*}{ Treatments } & \multicolumn{7}{c}{ Fungal Strains } \\
\cline { 2 - 8 } & P1 & P2 & P3 & P4 & HI & SB & ERY \\
\hline PD & $2.34 \mathrm{bA}$ & $1.95 \mathrm{bA}$ & $1.74 \mathrm{bB}$ & $1.97 \mathrm{bA}$ & $5.59 \mathrm{aA}$ & $4.68 \mathrm{aA}$ & $1.46 \mathrm{bA}$ \\
PD+AM 0.02 g L & $1.90 \mathrm{bA}$ & $1.42 \mathrm{bcA}$ & $3.13 \mathrm{aA}$ & $0.65 \mathrm{cB}$ & $2.89 \mathrm{aB}$ & $3.38 \mathrm{aB}$ & $1.17 \mathrm{bcAB}$ \\
PD+AM 0.04 g L & $0.44 \mathrm{~dB}$ & $1.56 \mathrm{bcA}$ & $2.47 \mathrm{abAB}$ & $1.19 \mathrm{cdB}$ & $3.40 \mathrm{aB}$ & $2.61 \mathrm{aC}$ & $0.69 \mathrm{cdB}$ \\
\hline
\end{tabular}

Equal lowercase letters in the same row and upper case in the same column indicate averages with no statistical difference for Tukey's HSD ${ }^{\mathrm{ab}}$ test at the $5 \%$ level of significance $(\mathrm{p}<0.05)$.

Among the seven strains of Pleurotus sp., the isolates HI and SB presented more extensive mycelial mass averages for the treatment of the PD medium, reaching $5.59 \mathrm{~g} \mathrm{~L}^{-1}$ and $4.68 \mathrm{~g} \mathrm{~L}^{-1}$, respectively. The same fungal strains, when grown at the different concentrations of methylene blue dye had a higher production of mycelial mass relative to the other strains and when compared to each other. The behavior of these two isolates presented mycelial mass averages without statistically significant differences, thereby indicating a good development of these two isolates in the treatments tested.

However, the analysis of the behavior of these strains in the solutions revealed that the strain HI showed a statistically equal growth between the two treatments with the methylene blue dye, indicating that regardless of the concentration the mass averages are statistically the same for this strain. That differed from the SB strain, presenting a distinct growth in the different treatments with its highest mycelial mass being found in the solution containing $0.02 \mathrm{~g} \mathrm{~L}^{-1}$ of the methylene blue dye.

The analysis of the mycelial growth of the strains in the treatment with $0.02 \mathrm{~g} \mathrm{~L}^{-1}$ and $0.04 \mathrm{~g} \mathrm{~L}^{-1}$ of the methylene blue dye showed that the isolate P3 did not present statistically significant differences with the isolates $\mathrm{HI}$ and SB and that only in the treatment with a higher concentration of the dye, strain $\mathrm{P} 3$ presented a mycelial mass average without any statistically significant difference from strain $\mathrm{P} 2$.

During the treatments with the methylene blue dye, the behavior of strain P3 showed that in the two concentrations of the dye, the growth was also statistically equal, indicating a good development of the strain in both the treatments. Table 2 shows that the lowest mass averages were found for fungal strains P1, P2, P4, and ERY in the treatments with $0.02 \mathrm{~g} \mathrm{~L}^{-1}$ and $0.04 \mathrm{~g} \mathrm{~L}^{-1}$ of the dye, and only isolate P1 presented a decline in growth between the two treatments with a statistically significant difference. Thus, among the fungal strains studied, isolates $\mathrm{HI}, \mathrm{SB}$, and $\mathrm{P} 3$ stood out in relation to the production of mycelial mass.

In our study, it was noticed that the mycelial growth of the strains varied with the increasing concentrations of the dye, showing that each strain presents a different behavior in relation to its growth, varying not only with the characteristics of the culture medium but also with the characteristics of the individual species.

The analysis of the absorbances, described in Figure 2 and Figure 3, demonstrated that all the isolates were visibly able to reduce the color of the medium following seven days of growth, thus corroborating with the results obtained by Babá et al. (2009). Through a visual analysis in that study, the color was observed to decrease when the PD culture medium containing the methylene blue dye was inoculated with an isolate of the fungus Pleurotus ostreatus. 


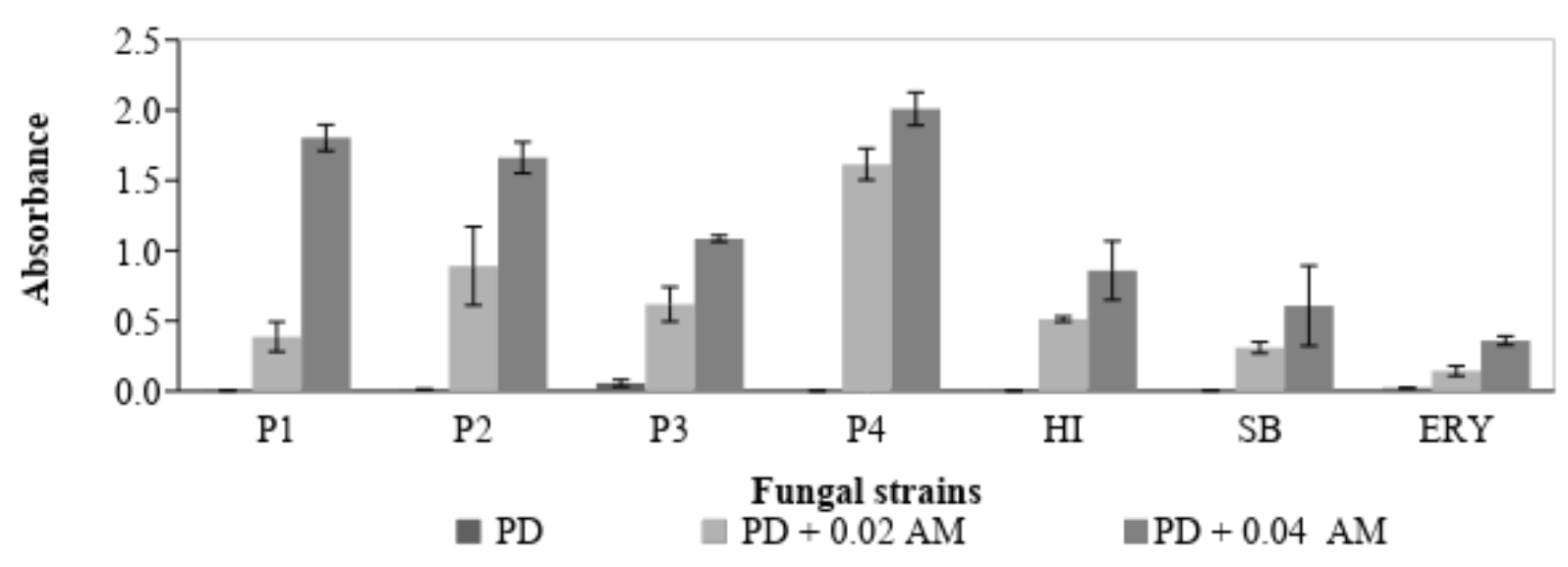

Figure 2. The absorbance of the solutions in which the Pleurotus strains (P1, P2, P3, P4, HI, SB, ERY) were cultivated. The medium without addition of methylene blue dye (PD), the medium with the addition of $0.02 \mathrm{~g} \mathrm{~L}^{-1}$ of methylene blue (PD + $0.02 \mathrm{AM}$ ) and the medium with the addition of $0.04 \mathrm{~g} \mathrm{~L}^{-1}$ of methylene blue (PD + 0.04 AM).

Figure 2 shows the results of the absorbances obtained for each treatment after the period of inoculation with the fungal strains. Comparing the absorbances of these treatments with their respective controls, it was possible to identify the reductions obtained for each of the solutions (Figure 3). However, only in the PD medium, the reduction in the color of the solution was not possible to verify because it was the control.

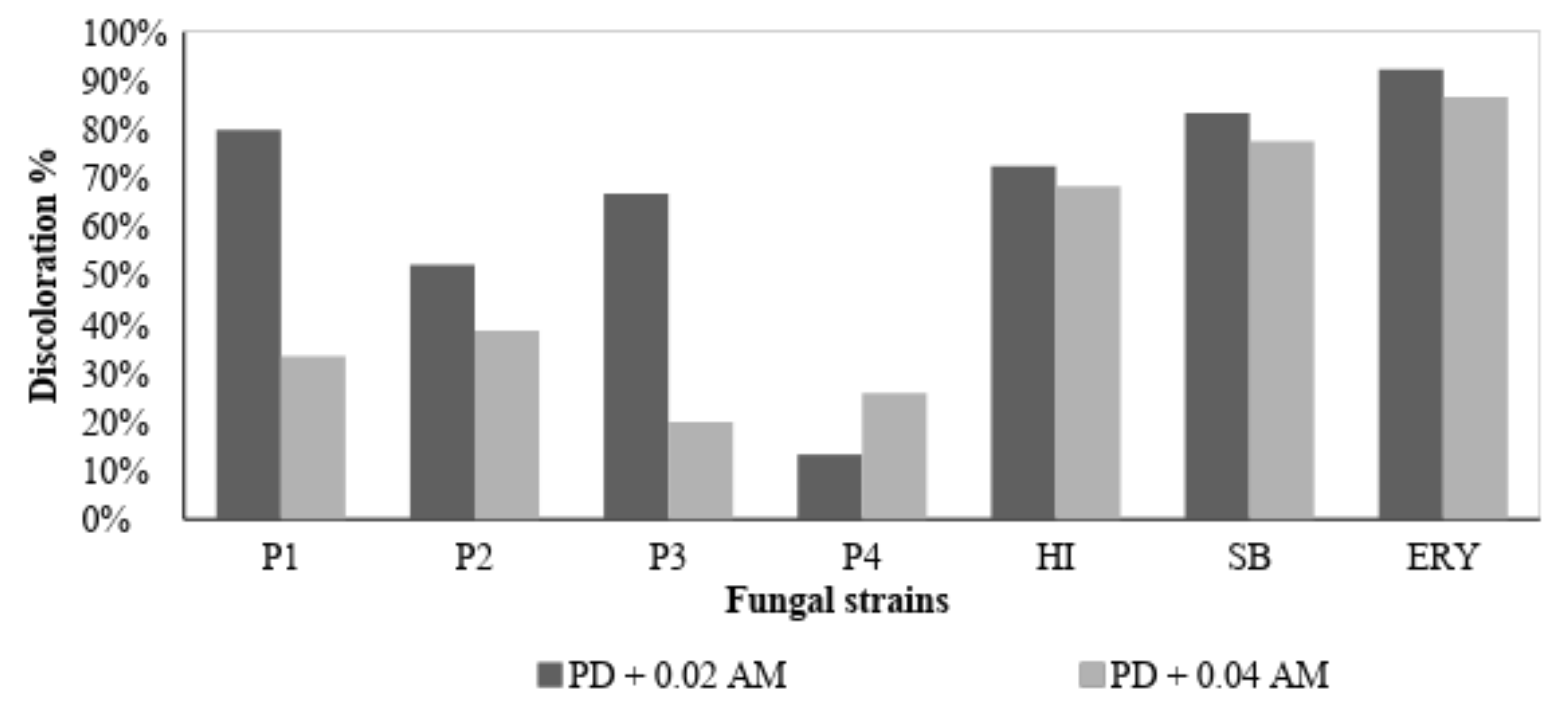

Figure 3. Percentage reduction of the absorbance of the initial solution in which the Pleurotus strains (P1, P2, P3, P4, HI, SB, ERY) were cultivated. The medium with the addition of $0.02 \mathrm{~g} \mathrm{~L}^{-1}$ of methylene blue (PD + $0.02 \mathrm{AM}$ ) and the medium with the addition of $0.04 \mathrm{~g} \mathrm{~L}^{-1}$ of methylene blue (Medium PD + 0.04 AM).

The values described in Figure 2 and Figure 3 indicated the decolorizing potential of the seven strains of Pleurotus sp. with reductions in the color of the methylene blue dye ranging between $13.3 \%$ to $92.3 \%$. Figure 3 also shows that almost all the fungal isolates presented greater reductions in the absorbances of the solution at both concentrations, indicating that these fungi present the ability to degrade this dye at the lowest concentration with the greatest efficiency. Only strain P4 presented a different behavior, because it showed a higher percentage of reduction in the absorbance of the solution with the PD medium, containing $0.04 \mathrm{~g} \mathrm{~L}^{-1}$ of the methylene blue dye, indicating that in this way the metabolism of each fungal strain can develop a different capacity, in order to metabolize compounds. 
Among all the fungal isolates, the ERY strain presented the best results with a $92.3 \%$ reduction in the absorbance for the treatment of the PD medium with $0.02 \mathrm{~g} \mathrm{~L}^{-1}$ of the methylene blue dye and a $86.7 \%$ reduction in the absorbance for the treatment of the PD medium with $0.04 \mathrm{~g} \mathrm{~L}^{-1}$ of the dye, compared to the treatments without fungal inoculation.

As shown in Table 2, the analysis of the treatment of the PD medium with $0.02 \mathrm{~g} \mathrm{~L}^{-1}$ of the methylene blue dye verified that the absorbance differences among the strains ERY, SB, HI, and P1 were not statistically significant, indicating that for this treatment they exhibit a similar efficiency in the removal of the color. On the other hand, it was also observed that in the PD + AM solution, containing $0.02 \mathrm{~g} \mathrm{~L}^{-1}$ of the dye, the strain P3 did not present statistically significant differences in relation to the strains SB and HI, thereby suggesting that this strain also shows a significant reduction in the color of this solution.

Table 2. The absorbance of the Pleurotus strains (P1, P2, P3, P4, HI, SB, ERY) for treatments in the medium without addition of the methylene blue dye (PD); in the medium with the addition of $0.02 \mathrm{~g} \mathrm{~L}^{-1}$ of methylene blue (PD + AM $0.02 \mathrm{~g} \mathrm{~L}^{-1}$ ); and in the medium with the addition of $0.04 \mathrm{~g} \mathrm{~L}^{-1}$ of methylene blue (PD + AM $0.04 \mathrm{~g} \mathrm{~L}^{-1}$ ).

\begin{tabular}{lccccccc}
\hline \multirow{2}{*}{ Treatments } & \multicolumn{7}{c}{ Fungal Strains } \\
\cline { 2 - 8 } & P1 & P2 & P3 & P4 & HI & SB & ERY \\
\hline PD & $0.01 \mathrm{aA}$ & $0.01 \mathrm{aA}$ & $0.06 \mathrm{aA}$ & $0.003 \mathrm{aA}$ & $0.004 \mathrm{aA}$ & $0.01 \mathrm{aA}$ & $0.02 \mathrm{a} \mathrm{A}$ \\
PD+AM $0.02 \mathrm{gL}^{-1}$ & $0.39 \mathrm{baB}$ & $0.89 \mathrm{cB}$ & $0.62 \mathrm{bcB}$ & $1.62 \mathrm{~dB}$ & $0.51 \mathrm{baB}$ & $0.31 \mathrm{baB}$ & $0.14 \mathrm{a} \mathrm{AB}$ \\
PD+AM $0.04 \mathrm{gL}^{-1}$ & $1.80 \mathrm{dC}$ & $1.66 \mathrm{dC}$ & $1.09 \mathrm{cC}$ & $2.01 \mathrm{dC}$ & $0.86 \mathrm{bcC}$ & $0.61 \mathrm{baC}$ & $0.36 \mathrm{aB}$ \\
\hline
\end{tabular}

Equal lowercase letters in the same row and upper case in the same column indicate averages with no statistical differences for Tukey's HSD ${ }^{\text {ab }}$ test at the $5 \%$ level of significance $(\mathrm{p}<0.05)$.

The analysis of the treatment with $0.04 \mathrm{~g} \mathrm{~L}^{-1}$ of methylene blue dye revealed that the strain ERY presented the lowest absorbance average and consequently, the highest reduction in the color between the treatments (Table 1). The strain ERY was the only isolate that did not present statistically significant differences between the two treatments to which it was subjected (Table 2). Some of the isolates were also seen to present a direct relationship between the growth of mycelial mass and the reduction in the absorbance, while the other isolates such as the strain ERY showed an inverse relationship.

The strains SB and HI showed statistical equality in the treatment with $0.04 \mathrm{~g} \mathrm{~L}^{-1}$ of the methylene blue dye with the performance of the strain SB being statistically equal to that of the strain ERY. When compared to the control treatments, the other strains showed high absorbance averages, thereby generating lower reductions in the color than these three strains.

For each isolate, the evaluation of the mean absorbances of the three treatments verified that the ERY, SB, and $\mathrm{HI}$ isolates presented reductions of over $60 \%$ in all the solutions. Thus, they were found to be most promising for the processes of bioremediation as they presented tolerance and efficiency in the removal of the color of methylene blue dye.

Rosolen et al. (2004) also carried out an evaluation of the capacity of the two strains Pleurotus ostreatus and Pleurotus sajor-caju in the degradation of the nine textile dyes, including Palanil Yellow 3G, Drimaren Yellow CL-R, Indanthren Yellow 5GF, Drimaren Red CL-5B, Indanthren Red FBB, Dispersol Red C-4G, Dispersol Blue C-2R, Drimaren Blue CL-R, and Indanthren Blue RCL. The authors verified that the above two strains were visibly able to discolor almost all the dyes, except Indanthren Red FBB, which presented a complex structure compared to the other dyes. The rate of degradation of the dyes in this work followed the growth rate of the fungi, indicating that the percentage of removal of the color was related to the capacity of the fungi to grow, differing from the present study, where it was verified that the strains such as ERY did not present such direct relationship. 
In the same work carried out by Rosolen et al. (2004), the toxicity of an effluent containing these dyes was tested and it was verified that the effluent treated with both the fungal strains presented a lower toxicity, indicating the efficiency of the fungal strains of the genus Pleurotus in the processes of removal of color and toxicity.

The data of work carried out by Bettin et al. (2011) also corroborates the results found in the present study, where it was possible to verify a 15-70\% discoloration of the dye Reactive Blue 220 when placed in contact with the crude enzyme extract of the fungal strain Pleurotus sajor-caju, suggesting that this strain presents a potential for the discoloration of textile dyes.

In another study by Bettin et al. (2011), the dye discoloration of chromophore groups such as anthraquinone, azo, and triphenylmethane during the growth of the Pleurotus sajor-caju strain PS-2001 was tested in Petri dishes and the discoloration of the dyes was verified visually, indicating that treatment with this fungal strain could be used in the biotechnological processes.

The fungi, belonging to the division Basidiomycetes are microorganisms with great capacities to biodegrade and mineralize diverse compounds, having the most varied structures. Among these compounds, the dyes represent a class of substances with complex chemical structures with the possibility of being broken into simpler molecules by the action of the extracellular enzymes produced by these fungi.

The fungi of the genus Pleurotus have a high capacity to produce enzymes, organic acids, and other metabolites that are capable of promoting the discoloration of the dyes and agroindustrial residues. Due to their lack of substrate specificity, these enzymes are also capable of degrading a variety of xenobiotics (Křesinová et al., 2018). Furthermore, the fungi of this genus differ in the degradation ability of these substances due to the qualitative and quantitative characteristics of their individual enzymes (Kamida et al., 2005).

In fact, fungi of the genus Pleurotus are known to be good producers of lignolytic enzymes, which are capable of oxidizing xenobiotic compounds as well as dyes, showing a correlation between the lignolytic enzymes and the discoloration of compounds (Vilar et al., 2018).

Corroborating these findings with the present work, we can highlight the capacity of the genus Pleurotus in bioremediation processes, thereby indicating the importance of the selection of isolates, since strains from the same genus or even the same species can behave in different ways against environmental degradation.

\section{CONCLUSIONS}

The analysis of the growth of fungal biomass showed that the seven strains of Pleurotus sp. tested in this study are able to grow under atypical conditions with different concentrations of the methylene blue dye, thereby indicating their potential to be used in bioremediation processes.

The results concerning the performance of the seven strains of Pleurotus sp. in the degradation of the methylene blue dye showed significant reductions in the absorbances of the solutions after the incubation period. The discoloration of both the culture media, with dye at concentrations of $0.02 \mathrm{~g} \mathrm{~L}^{-1}$ and $0.04 \mathrm{~g} \mathrm{~L}^{-1}$, was successfully achieved by the strains of Pleurotus sp., designated as ERY, HI, and SB with a reduction of around $80 \%$ in the absorbance.

The tests showed that despite contributing to the discoloration of the solutions tested, the amount of biomass production is not a determining factor, since the strain ERY presented a lower production of mycelial mass but reached the highest values in reducing the color of the substrate containing the methylene blue dye. 


\section{ACKNOWLEDGMENTS}

The authors are grateful to Fundação de Amparo à Pesquisa do Estado de Minas Gerais (FAPEMIG) and Conselho Nacional de Desenvolvimento Científico e Tecnológico (CNPq).

\section{REFERENCES}

ATAGANA, H. I.; HAYNES, R. J.; WALLIS, F. M. Fungal Bioremediation of creosote contaminated soil: a laboratory scale bioremediation study using indigenous soil fungi. Water Air and Soil Pollution, v. 172, p. 201-219, 2006. https://dx.doi.org/10.1007/s11270-005-9074-X

BABÁ, A. Y.; ROSADO, F. R.; ZONETTI, P. C. Biorremediação de efluentes líquidos por meio da ação de Pleurotus sp. In: ENCONTRO INTERNACIONAL DE PRODUÇÃO CIENTÍFICA CESUMAR, 5., 27-30 2009, Paraná. Anais... Paraná, 2009. Disponivel em: https://goo.gl/wWciJh. Acesso em: 10 mar. 2016.

BETTIN, F.; ROSA, L. O.; MONTANARI, Q.; CALLONI, R.; GAIO, T. A.; MALVESSI, E. et al. Growth, kinetics, production, and characterization of extracellular laccases from Pleurotus sajor-caju PS-2001. Process of Biochemistry, v. 46, p. 758-764, 2011. https://dx.doi.org/10.1016/j.procbio.2010.12.002

CAJTHAML, T. Biodegradation of endocrine-disrupting compounds by ligninolytic fungi: mechanisms involved in the degradation. Environmental Microbiology, v. 12, p. 48224834, 2015. https://dx.doi.org/10.1111/1462-2920.12460

CONFORTIN, F. G.; MARCHETTO; R.; BETTIN, F.; CAMASSOLA, M.; SALVADOR, M.; DILLON, A. J. P. Production of Pleurotus sajor-caju strain PS-2001 biomass in submerged culture. Journal of Industrial Microbiology and Biotechnology, v. 35, p. 1149-1155, 2008. https://dx.doi.org/10.1007/s10295-008-0394-X

GUPTA, V. K.; RASTOGI, A. Biosorption of hexavalent chromium by raw and acid treated green alga Oedogonium hatei from aqueous solutions. Journal of Hazardous Materials, v. 163, p. 396-402, 2009. https://dx.doi.org/10.1016/j.jhazmat.2008.06.104

KAMIDA, H. M.; DURRANT, L. R.; MONTEIRO, R. T. R; ARMAS, E. D. Biodegradação de Efluente Têxtil por Pleurotus sajor-caju. Química Nova, v. 28, p. 629-632, 2005. http://dx.doi.org/10.1590/S0100-40422005000400014

KŘESINOVÁ, Z.; LINHARTOVÁ, F.; EZECHIÁŠ, M.; MAŠÍN, P.; CAJTHAML, T. Biode gradation of endocrine disruptors in urban wastewater using Pleurotus ostreatus bioreactor. New Biotechnology, v. 43, p. 53-61, 2018. https://dx.doi.org/10.1016/j.nbt.2017.05.004

POZDNYAKOVA, N.; DUBROVSKAYA, E.; CHERNYSHOVA, M.; MAKAROV, O.; GO LUBEV, S.; BALANDINA, S. et al. The Degradation of three-ringed po lycyclic aromatic hydrocarbons by wood-inhabiting fungus Pleurotus ostreatus and soil-in habiting Fungus Agaricus bisporus. Fungal Biology, v. 30, p. 1-10, 2018. https://dx.doi.org/10.1016/j.funbio.2018.02.007

PRZYSTAŚ, W.; GODLEWSKA, E. Z.; SOTA, E-G. Efficiency of decolorization of diffe rent dyes using fungal biomass immobilized on different solid supports. Environmental Microbiology, v. 49, p. 285-295, 2018. http://dx.doi.org/10.1016/j.bjm.2017.06.010

\section{IPABH}

Rev. Ambient. Água vol. 13 n.4, e2247 - Taubaté 2018 
ROSOlEN, L. A.; MONTEIRO, R. T. R.; DELlamATRICE, P. M.; KAMIDA, H. M. Biodegradação de efluente têxtil e nove corantes técnicos utilizando fungos basidiomicetos. Revista Química Têxtil, v. 76, p. 26- 32, 2004.

SANTANA, M. D. F.; RODRIGUES, L. S. I; AMARAL, T. S.; PINHEIRO, Y. G. Fenoloxidase e biodegradação do corante têxtil azul brilhante de remazol para três espécies de macrofungos coletadas na Amazônia. SaBios: Revista de Saúde e Biologia, v. 11, p. 53-60, 2016.

SOARES, G. M. B.; COSTA-FERREIRA, M.; AMORIM, M. T. P. Decolorization of an anthraquinone-type dye using a laccase formulation. Bioresource Technology, v. 79, p. 171-177, 2011. https://dx.doi.org/10.1016/S0960-8524(01)00043-8

VILAR, D. S.; CARVALHO, G. O.; PUPO, M. M. S.; AGUIAR, M. M.; TORRES, N. H.; AMÉRICO, J. H. P. et al. Vinasse degradation using Pleurotus sajor-caju in a combine d biological - Electrochemical oxidation treatment. Separation and Purification Technology, v. 192, p. 287-296, 2018. https://dx.doi.org/10.1016/j.seppur.2017.10.017

ZHUO, R.; YUAN, P.; YANG, Y.; SHU Z, M. A. F.; ZHANG, X. Induction of lacase by metal ions and aromatic cinpounds in Pleurotus ostreatus HAUCC 162 and discolorization of different sythetic dyes by extracelular laccase. Biochemistry Engineering Journal, v. 117, p. 62-72, 2017. https://dx.doi.org/10.1016/j.bej.2016.09.016 